\title{
Heat treatment-induced autophagy promotes invasion and metastasis via TGF- $\beta 2$ mediated epithelial-mesenchymal transition in breast cancer cells
}

\section{Zhen-Nan Li}

Affiliated Obstetrics and Gynecology Hospital of Nanjing Medical University

Cheng Lu

Affiliated Obstetrics and Gynecology Hospital of Nanjing Medical University

Feng-Liang Wang

Affiliated Obstetrics and Gynecology Hospital of Nanjing Medical University

Hao-Wei Guo

Affiliated Obstetrics and Gynecology Hospital of Nanjing Medical University

\section{Zhi-Peng Wang}

Affiliated Hospital of Jiangsu University

Ping Zhou

Affiliated Obstetrics and Gynecology Hospital of Nanjing Medical University

Hong Yin

Affiliated Obstetrics and Gynecology Hospital of Nanjing Medical University

Jian Li ( $D$ lijian541226@163.com )

Affiliated Hospital of Jiangsu University

\section{Research Article}

Keywords: Breast cancer, microwave ablation, sublethal heat treatment, autophagy, epithelialmesenchymal transition, metastasis

Posted Date: November 18th, 2021

DOI: https://doi.org/10.21203/rs.3.rs-1068191/v1

License: (1) This work is licensed under a Creative Commons Attribution 4.0 International License. Read Full License 


\section{Abstract \\ Background}

Insufficient thermal ablation can cause accelerated malignant behaviors and increased metastasis in hepatocellular carcinoma (HCC), and epithelial-mesenchymal transition (EMT) and autophagy are implicated in tumor metastasis. However, whether interactions between autophagy and TGF- $\beta 2$ induce EMT in breast cancer (BC) after insufficient microwave ablation (MWA) remains unclear.

\section{Methods}

In this study, we treated BC cells with sublethal heat treatment for simulating insufficient MWA, and then the effect of heat treatment on the BC cell phenotypes were explored. CCK-8, colony formation, flow cytometry, transwell and wound healing assays were performed to evaluate the influence of sublethal heat treatment on the proliferation, apoptosis, invasion and migration of $\mathrm{BC}$ cells treated with/without autophagy inhibitors. Western blotting, real-time quantitative PCR, immunofluorescence and transmission electron microscopy were carried out to determine the changes of markers associated with autophagy and EMT after sublethal heat treatment. Xenograft models in mice were established by using sublethal heat treated $\mathrm{BC}$ cells to investigate the effect of autophagy inhibitor on BC tumor growth in vivo.

\section{Results}

Results showed that heat treatment promoted the proliferation of survived $\mathrm{BC}$ cells, which was accompanied by autophagy induction. Heat treatment-induced autophagy up-regulated TGF- $\beta 2 / S m a d 2$ signaling and promoted phenotype of EMT, thereby enhancing abilities of migration and invasion in BC cells. Increase or decrease of TGF- $\beta 2$ expression resulted in potentiation and suppression of autophagy as well as enhancement and abatement of EMT. Autophagy inhibitor facilitated apoptosis and repressed proliferation of BC cells in vitro, and thwarted BC cell tumor growth and pulmonary metastasis in vivo.

\section{Conclusions}

This study indicate that heat treatment-induced autophagy promotes invasion and metastasis via TGF$\beta 2 / S m a d 2-m e d i a t e d ~ E M T$. Suppressing autophagy might be a new strategy for overcoming sufficient MWA caused progression and metastasis of residual BC cells.

\section{Introduction}

Breast Cancer (BC) is the most common cancer and the leading cause of cancer-related death among women worldwide [1]. Surgical treatment of $\mathrm{BC}$ has evolved from radical mastectomy to breast conservation therapy. Other treatment modalities are also developing, such as minimally invasive 
ablation techniques including cryotherapy, radiofrequency, microwave and laser ablation [2-5]. There are many advantages for ablation treatment of $\mathrm{BC}$ including lower treatment cost, less general anesthesia, lower the complication rate and severity of these, shorter recovery time and better cosmetic results, and appropriate option for elderly patients with comorbidities that led to their unfit for surgery [5-7]

In the past decade, microwave ablation (MWA) has attracted increasing attention due to its potential advantages including larger ablation area and high intratumoral temperature produced by active heating as compared with other thermal ablation techniques [8-10]. However, for MWA procedure to be considered technically successful, the tumor and an enough safety margin of normal breast tissue must be completely included in the ablation zone, therefore the primary problem using MWA is its difficulty in achieving complete tumor inactivation $[6,7,9]$. Previous studies showed that although MWA can result in complete tumor destruction in the most cases, residual tumor was still observed in a few of patients and animal models $[9,11,12]$. In hepatocellular carcinoma (HCC), the residual tumor after thermal ablation showed accelerated malignant behaviors and a aggressive progression [13, 14]. The residual tumor is the major factor that affects the efficacy and the survival time of patients receiving thermal ablation $[15,16]$. Multifaceted factors have been proposed to be involved in the more malignant phynotype of residual tumor and the accelerated local progression in HCC after insufficient thermal ablation. For example, Liu et al reported that sublethal heat treatment promoted HCC cell proliferation through an increased expression of vascular endothelial growth factor (VEGF) by CaMK囚-induced ERK activation [13]. Another study showed that insufficient thermal ablation could facilitate the growth and metastasis of residual hepatic VX2 carcinoma owing to the induction of over-expressions of PCNA, VEGF and MM-2 [17]. Accumulative evidence revealed that sublethal heat treatment could activate epithelial-mesenchymal transition (EMT) process and provoke morphological transformation in the survival HCC cells $[18,19]$. Recent studies have highlighted that the autophagy activation plays an important role in proliferation and progression of HCC after insufficient thermal ablation [14,20]. In BC, only one study reported that insufficient MWA promoted EMT of residual BC cells by activating the $\beta$-catenin signaling pathway, resulting in enhanced distant metastasis of residual BC cells [21]. However, the role of autophagy in the change of invasion and metastasis abilities of residual BC cells after insufficient MWA is unknown. A growing body of evidence indicated that EMT and autophagy are two major biological processes in the occurrence and development of cancer, and there is a complex relationship between the EMT-correlated and the autophagy-correlated signaling pathways $[22,23]$. This led us to hypothesize that insufficient MWA could induce autophagy which promote EMT-caused invasion and metastasis of residual BC cells.

In the present study, we showed the evidences that autophagy play a key role in the modulation of biological status of heat-treated residual BC cells as the following: (1) BC cells survived sublethal heat treatment through autophagy induction; (2) autophagy promoted the EMT of heat-treated residual BC cells by up-regulating the TGF- $\beta_{2} /$ Smad2 signaling; (3) the reciprocal interactions of autophagy and TGF$\beta_{2}$ promoted-EMT enhanced the abilities of invasion and migration of heat-treated residual $B C$ cells, and the AKT/mTOR pathway was involved in this process; (4) autophagy inhibitor suppressed proliferation 
and increased apoptosis of heat-treated BC cells in vitro, and thwarted tumor growth and metastasis by repressing EMT and augmented heat-induced apoptosis in vivo.

\section{Materials And Methods}

\section{Cell culture and heat treatment}

The human BC cell lines MCF-7 and MDA-MB-231 (MDA-231) were obtained from Cell Bank of the Chinese Academy of Sciences (Shanghai, China) and cultured in minimal essential medium (MEM) with $10 \%$ fetal calf serum (FCS), 2 mM L-glutamine, non-essential amino acids, $1 \mathrm{mM}$ sodium pyruvate, 100 units $/ \mathrm{ml}$ penicillin and $100 \mu \mathrm{g} / \mathrm{ml}$ streptomycin. The cells were maintained in a humidified atmosphere of $5 \% \mathrm{CO}_{2}$ at $37^{\circ} \mathrm{C}$.

MCF-7 and MDA-231 cells were grown on the 6-well plates (5x10 4 cells/well), and after $24 \mathrm{~h}$ incubation they were exposed to heat treatment. Heat treatment was performed by sealing the tops of culture plates with parafilm and submerging the flasks or plates in a water bath set to the predetermined temperature for the indicated duration. According to the results of autophagy detection, heat-induced autophagy was especially marked at $47^{\circ} \mathrm{C}$ for $30 \mathrm{~min}$ (See Figure $2 \mathrm{~A}$ and $\mathrm{B}$ ), we selected heat treatment of $47^{\circ} \mathrm{C}$ for 30 min to simulated the effects of insufficient MWA and maintained at $37^{\circ} \mathrm{C}$ as the control in vitro. After heat treatment, cells were cultured at $37^{\circ} \mathrm{C}$ for recovery.

\section{Antibodies and reagents}

Chloroquine (CQ), 3-methyladenine (3-MA), rapamycin and TGF- $\beta_{2}$ were purchased from Sigma-Aldrich (St Louis, MO, USA). LY2109761 and 740 Y-P were from Selleck Chemicals (Houston, TX, USA). Antibodies against microtubule-associated protein 1 light chain 3-囚(LC3-囚), LC3-囚, p62, Beclin 1, ATG7, poly (ADP-ribose) polymerase (PARP), cleaved-PARP, caspase 9, cleaved-caspase 9, Bax, Bel-x1, AKT, pAKT, AMPK, p-AMPK, mTOR, p-mTOR, S6K1 and p-S6K1 were from Abcan Inc (Combride, MA, USA). Antibodies against TGF- $\beta_{2}$, Smad2, p-Smad2, E-cadherin, $\alpha$-catenine, $\beta$-catenin, $N$-cadherin, fibronectin, ZO-1, Vimentin, MMP-9, Snail, Slug and $\beta$-actin were from Santa Cruz Biotechnology (Santa Cruz, CA, USA). Primary antibodies of LC3-囚and E-cadherin and second antibodies Alexa Fluor 568 anti-mous IgG and Alexa Flour 568 anti-rabbit antibodies were from Jackson Immuno Research (Lancaster, PA USA).

\section{Cell viability and clonogenic assays}

Cells were seeded into 96 -well plates at a density of $1 \times 10^{4}$ cells per well and cultured overnight for attachment. Then cells were exposed to heat treatment, and/or 3-MA for the indicated times. After incubation for $24,48,72,96$, and $120 \mathrm{~h}$, cell viability was determined using a Cell Counting Kit-8 (CCK-8) assay (DoJindo, Tokyo, Japan), according to manufacture's instruction as previously reported [24]. The absorbance was measured at a wavelength of $450 \mathrm{~nm}$ with a reference wavelength of $650 \mathrm{~nm}$ using a microplate reader. 
Cell colony formation ability was assessed by clonogenic assay as previously reported [24]. Briefly, cells were seeded into 6-well dishes at a concentration of $1 \times 10^{3}$ cells/well and allowed to grow in complete medium for 14 days after treatment with the indicated temperatures and/or drugs. The colonies obtained were washed with PBS and fixed in 4\% paraformaldehyde for 20 min at room temperature, followed by staining with crystal violet. The colonies were counted and compared with untreated cells (control).

\section{Analysis of cell apoptosis}

The percentage of apoptostic cells was determined using flow cytometry with the Annexin V-FITC PI staining in accordance with the manufacturer's protocol as previously described [25]. In addition, a Hoechst 33258 staining Kit (Beyotime, China) was used to detect apoptotic cell features. Cell were seeded into a 6 -well plate $\left(1 \times 10^{5}\right.$ cells/well), cultured for $24 \mathrm{~h}$ and, subsequently, treated with the indicated temperature and/or agents, then stained with Hoechst 33258. Apoptotic morphologic features (chromation condensation and nuclear fragmentation) were evaluated and imaged using fluorescent microscope.

\section{Western blotting and real-time quantitative PCR analysis}

Before and after treatment with the indicated temperature and/or agents, or transfections with the siRNA against the indicated genes, whole lysate proteins extracted from the cells were prepared and analyzed by standard western blotting as previously described [25]

For real-time quantitative PCR analysis, total RNA was extracted from cell samples using Trizol reagents (Invitrogen, Carlsbad, CA, USA) following the manufacturer's instructions. RNA (1 2 $\mu \mathrm{g}$ ) was reversely transcribed into cDNA using the Super Script $\otimes$ First-Strand Synthesis Kit (Invitrogen, Carlsbad, CA, USA) according to the manufacturer's instructions, and the reactions were run on an BAI 7500 Fast real-time PCR system, as previously reported [24]. Detection of PCR products was accomplished by measuring the emitting fluorescence $(\mathrm{Rn})$ at the end of each reaction step. mRNA relative quantification was calculated with the $\mathrm{Ct}\left(2^{-\Delta \Delta \mathrm{Ct}}\right)$ method.

\section{Small interfering RNA transfection}

All siRNA reagent used in this study were purchased from Guangzhou Ribobio Co., Ltd (China). Before treatment with the indicated temperature, cells were transfected with Lipofectamine 2000 reagents according to the manufacturer's instructions as previously described [24]. The efficacy of transfection were verified by western blotting.

\section{Immunofluorescence and MDC staining}

LC3-『 puncta was detected by immunofluorescent staining, as previously reported [25, 26]. Briefly, cells were seeded into 96-well plates, and treated with the indicated temperature or/and agents before being fixed with $2 \%$ paraformaldehyde in PBS for $20 \mathrm{~min}$ at $37^{\circ} \mathrm{C}$. Following permeabilization for 3 min with PBS- $0.2 \%$ Triton X-100, the cells were incubated overnight at $4{ }^{\circ} \mathrm{C}$ with anti-LC3 antibody diluted 1:100. Then the cells were incubated for $1 \mathrm{~h}$ at room temperature with Alexa Fluor 488-conjugated secondary 
antibody at a 1:400 dilution. Then cells were counterstained with Hoechst 33342 for 5 min for nuclear staining, and mounted on glass slides, cells were visualized using a Leica Confocal Laser Scanning Microscope (Leica, Wetzlar, Gemany).

The formation of acidic vascular organelles (AVOs) was detected using monodansylcadaverine (MDC) staining as previously reported $[25,26]$. Briefly, cells were seeded on the 24-well plates and treated with the indicated temperature or/and agents. Then the cells were incubated with $0.5 \mathrm{mM} \mathrm{MDC}$ for $2 \mathrm{~h}$ in serum-free medium at room temperature. The cellular fluorescent changes were detected at an excitation of $380 \mathrm{~nm}$ and a emission of $510 \mathrm{~nm}$ and observed under an epi-fluorescence microscope (Olympus, Tokyo, Japan).

For the detection of the intracellular localization of the proteins, cells were seeded on gelatin-coated coverslips and treated with the indicated temperature and/or agents. Then cells were fixed with $4 \%$ paraformaldehyde for 15 min, permeabilized with $0.1 \%$ Triton X-100 for 10 min and blocked with $0.5 \%$ BSA for $30 \mathrm{~min}$. Target proteins in cells were visualized by incubation with the corresponding antibodies overnight, followed by incubation with FITC-conjugated secondary antibodies for $1 \mathrm{~h}$. Rhodamineconjugated phalloidin and 4, 6-diamidino-2-phynylindol (DAPI) were subsequently used to localized Factin and nuclear. Images were acquired with a confocal microscope (Leica, Wetzlar, Germany).

\section{Transmission electron microscopy (TEM)}

Autophagies were observed by TEM as previously reported [25]. Briefly, cells $\left(10 \times 10^{6} \mathrm{cell} / \mathrm{ml}\right)$ were treated with the indicated temperatures, then fixed with karanovsky's fixation for $1 \mathrm{~h}$ at room temperature. Dehydration was performed with graded ethanol and propylence oxide, and cells were embedded in Araldite kit (Merck, Rahway, NT). Ultrathin section were prepared on an LKB囚 Ultratom by using a diamond knife (Diatome, Switzerland and SPI, USA), and the sections were mounted on Formvar-coated 200-mesh nicked grids. Grids were double stained for $1 \mathrm{~h}$ with saturated uranyl acetate in $50 \%$ methanol. The sections were examined in a JEOL-100 CX transmission electron microscope, at $80 \mathrm{KV}$.

\section{Cell migration and invasion assays}

Cell migration was determined by wound healing assay as previously reported [26]. After heat treatment, cells were cultured for $24 \mathrm{~h}$ and grown in medium containing 10\% FBS to nearly confluent cell monolayer, then carefully scratched using pipette tips to create a denuded zone (gap) of constant width.

Subsequently, cellular debris washed with PBS. The wound closure was monitored and photographed at 0 and $72 \mathrm{~h}$ under a Levia inverted microscope (Olympus, Tokyo, Japan). To quantify the migrated cells, pictures of the initial wounded monolayers were compared with the corresponding pictures of cells at the end of the incubation.

Cell invasion was determined by membrane transwell culture system. Transwell membrane coated with Matrigel was used for invasion assay as previously reported [26]. After treatment with the indicated temperature and/or agents, cells were seeded on the upper wells of precoated transwell, $2 \times 10^{4}$ cells for per well. Lower wells of the transwells contained the same medium with $10 \% \mathrm{FBS}$. After $48 \mathrm{~h}$ of 
incubation, the cells on the upper well and the membranes coated with Matrigel were swabbed with a Qtip, fixed with methanol, and stained with $20 \%$ Giemsa solution. The cells that were attached to the lower surface of the polycarbonate filter were counted under an inverted microscope (the percentage of invaded cells in control is designed as $100 \%$ ).

\section{In vivo xenograft tumor assay}

Female BALB/c nude mic (specific pathogen-free grade, 5-6 weeks of age) were obtained from the Modal Animal Research Center of Nanjing University (Nanjing, China) and maintained under standard pathogenfree conditions. All animal procedures were performed in accordance with the protocols approved by the Institutional Animal Care and Use Committee of the Jiangsu University. MDA-231 cells were pretreated for $47^{\circ} \mathrm{C}$ for 30 min or maintained at $37^{\circ} \mathrm{C}$ (control). After recovery at $37^{\circ} \mathrm{C}$ for $24 \mathrm{~h}$, cells $\left(5 \times 6^{6}\right.$ cells in 100 $\mu \mathrm{l}$ of serum-free RPMI 1640 medium) were subcutaneously injected into the mammary fat pad of 20 nude mice. Mice were divided into four group ( $n=5$ per group): vehicle $\left(37^{\circ} \mathrm{C}\right.$ treatment), $C Q\left(37^{\circ} \mathrm{C}\right.$ treatment), heat treatment $\left(47^{\circ} \mathrm{C}\right)$, and a combination of $\mathrm{CQ}$ and heat treatment. Starting on the second day, mice in vehicle and heat treatment group received intraperitoneal injections of $100 \mu \mathrm{l}$ of PBS thrice weekly, while mice in CQ and combination treatment groups received intraperitoneal injections of $60 \mathrm{mg} / \mathrm{kg}$ CQ in 100 $\mu \mathrm{l}$ of PBS thrice weekly for a total of 15 injections. Tumor size was measured every 1 week for 6 weeks, and tumor volumes were calculated using the formula: $V=\left(\right.$ Length $x$ Width $\left.{ }^{2}\right) / 2$. By the end of the experiment, mice were euthanized and the tumors were excised and weighed, and half of the tumor samples was fixed for histological examination and immunohistochemical staining. The remaining tumor samples were stored at $-80^{\circ} \mathrm{C}$ for western blotting.

\section{Tail vein metastatic assays}

MDA-231 cells pretreated with $47^{\circ} \mathrm{C}$ and maintained at $37^{\circ} \mathrm{C}$ were suspended in $100 \mu \mathrm{l}$ PBS and injected through tail vein into female BALB/c nude mice respectively. Mice were divided into 3 group $(n=5$ per group): vehicle $\left(37^{\circ} \mathrm{C}\right.$ treatment), heat treatment $\left(47^{\circ} \mathrm{C}\right)$ and a combination of heat treatment and $\mathrm{CQ}$. One day after tail vein injection, mice of vehicle and heat treatment groups received intraperitoneal injections of $100 \mu \mathrm{l}$ of PBS thrice weekly, while mice in combination treatment group received intraperitoneal injections of $60 \mathrm{mg} / \mathrm{kg}$ CQ in $100 \mu \mathrm{l}$ of PBS thrice weekly. Four weeks after the injection treatment, the mice were sacrificed and the lung tissues were isolated and made into serial sections for hematoxylin \& eosin (HE) staining and observed under a light microscope for counting the number of pulmonary metastatic foci.

\section{Statistical analysis}

All the experiments were performed in triplicate, and the results are presented as the mean $\pm S D$. For comparisons of two groups, a two-tailed unpaired t-test was used; for comparison of multiple groups, one-way ANOVA analysis followed by Tukey post hoc tests were applied. P-values $<0.05$ were considered significant. All statistical data were analyzed using SPSS (version 24.0) or GraphPad Prism (7.0 version) software. 


\section{Results}

\section{Sublethal heat treatment induces apoptosis but promotes proliferation of survived BC cells in vitro}

We first examined the effect of heat treatment on the viability of BC cells. MCF-7 and MDA-231 cells were exposed to heat treatment with $42^{\circ} \mathrm{C}$ and $47^{\circ} \mathrm{C}$ respectively for 30 min to simulate the insufficient MWA. Cells incubated at $37^{\circ} \mathrm{C}$ served as the control. Thereafter, heat-treated cells were cultured at $37^{\circ} \mathrm{C}$ for recovery. After continuous incubation for $24,48,72,96$ and 120 h, cells viability was determined by a CCK-8 assay at the corresponding time points. Comparing with control cells treated with $37^{\circ} \mathrm{C}$, the viability rates of the cells treated with $42^{\circ} \mathrm{C}$ and $47^{\circ} \mathrm{C}$ gradually decreased in a temperature-dependent manner in the initial 4 days. However, cells treated with $47^{\circ} \mathrm{C}$ showed an increase of viability rate at fifth days after heat treatment (Fig. 1A, B). Meanwhile, heat treatment induced cell apoptosis temperaturedependently (Fig. 1C), which was paralleled by an increase of cleaved-PARP, cleaved-caspase 9, and Bax, and a decrease of $\mathrm{Bcl}-\mathrm{x} 1$ in a time-dependent manner (Fig. 1E). It is worth nothing that heat-treated cells displayed increased colony formation abilities in comparison with cells treated with $37^{\circ} \mathrm{C}$ (Fig. 1D). The data suggest that heat treatment promotes proliferation of the $\mathrm{BC}$ cells in the later stage, although cell viability rates are reduced at the initial stage of heat treatment.

\section{Sublethal heat treatment induces autophagy of BC cells in vitro}

Since that sublethal heat treatment induces autophagy in Hela, A549 and HCC cells [20,27], we tested whether this phenomenon can also occur in BC cells by detecting the changes of autophagy-associated proteins in heat-treated surviving BC cells. Increased protein expressions of LC3- $\$ and Beclin 1, and decreased protein expression of p62 were observed in heat-treated $\mathrm{BC}$ cells compared with control cells (Fig. 2A), the changes of these proteins in a time-dependent manner were demonstrated by western blotting (Fig. 2B). Then we analyzed autophagosome formation by LC3-\ immunofluorescent staining. Heat treatment temperature-dependently augmented the formation of autophagosome as indicated by an increase of LC3-X-positive puncta in MCF-7 and MDA-231 cells (Fig. 2C). The MDC staining of heat-treated cells showed a temperature-dependent increase of fluorescence intensity value (Fig. 2D), which are indicative of acidic vesicular organelles (AVOs) including lysosome and autolysosome. Further examination by transmission electron microscopy (TEM) revealed an increased number of autophagosome in heat-treated BC cells (Fig. 2E). Because the accumulation of LC3-囚 protein is attributed to an increase in autophagosome formation or decrease in lysosomal degradation. To discriminate between these two possibilities, we treated the cells with a lysosomal inhibitor CQ. The results showed that CQ treatment resulted in further accumulation of LC3- $\mathrm{X}$ in the heat-treat cells (Fig. 2F). These observations clearly indicate that autophagy is constitutively activated in sublethal heat treated $\mathrm{BC}$ cells. 


\section{Heat-induced autophagy promotes EMT in BC cells by up- regulating TGF- $\beta 2 / S m a d 2$ signaling}

As autophagy was reported to be necessary for TGF- $\beta 2$ induced EMT through Smad2 signal in HCC cells [28]. We asked whether the heat-induced autophagy facilitate MET in BC cells by up-regulating TGF $\beta 2 / \mathrm{Smad} 2$ signaling pathway. We therefore examined the effect of autophagy induction or inhibition on TGF- $\beta 2$ and EMT, and explore the reciprocal role between autophagy and TGF- $\beta 2$ in the process. Results found that heat treatment not only activated autophagy, but also up-regulated TGF- $\beta 2$ expression. Cotreatment with 3-MA, a inhibitor of autophagosome formation, suppressed both heat-induced autophagy and TGF- 32 expression (Fig. 3A, B and Additional file 1: Figure S1). Similar results were obtained in the BC cells co-treated with ATG7 knocked down and heat exposure (Fig. 3C and Additional file 2: Figure S2AC). To inhibit the TGF- $\beta 2$ signaling pathway in BC cells, we co-treated the cells with heat exposure and

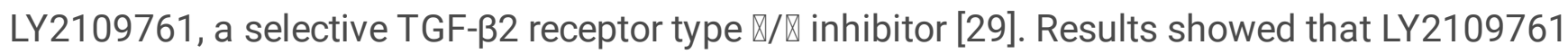
attenuated heat treatment induced TGF- $\beta 2$ up-regulation, and impeded Smad2 phosphorylation, and also suppressed autophagy induction (Fig. 3D, E and Additional file 3: Figure S3A). Furthermore, we treated the BC cells with TGF- $\beta 2$ to directly stimulate FGF- $\beta 2 /$ Smad2 pathway, a significant augmentation of Smad2 phosphorylation and autophagy levels were observed, which was similar to the result in the cells treated with rapamycin, a autophagy inducer (Additional file 3: Figure S3B).

Since TGF- $\beta 2$ is well-known inducer of EMT [30], we next detected EMT molecule marker expressions after heat treatment by western blotting and real-time PCR. Results revealed that heat treatment clearly increased protein expressions of mesenchymal and promigratory markers, such as N-cadherin, fibronectin, vimentin, snail, slug and MMP-9, concurrently reduced protein expressions of epithelial markers such as E-cadherin, a-catenin, $\beta$-catenin and ZO-1 (Fig. 3G and Additional file 4: Figure S4A). Real-time PCR analysis showed similar changes in transcript levels of these EMT associated markers after heat treatment. Moreover, co-treatment with 3-MA abated heat treatment-caused the changes of the EMT associated markers in protein and mRNA levels (Fig. 3G and Additional file 4: Figure S4A-E).

By immunofluorescence, we found that LC3-囚and E-cadherin were colocalized in the perinuclear regions after heat treatment, which were blocked by addition of 3-MA (Fig. 3F), suggesting that heat-induced autophagy could entrap E-cadherin from plasma membrane into the autophagosome and those trapped proteins might be degraded by lysosome. Taken together, the findings indicate that heat treatment induced autophagy up-regulated TGF- $\beta 2 /$ Smad2 signaling and thereby promoting the EMT of BC cells, in turn up-regulated TGF- $\beta 2$ facilitate autophagy induction.

\section{Heat-induced autophagy enhances the abilities of migration and invasion in BC cells through TGF- $\beta 2$ mediated EMT}

EMT is considered to be a major driver of cancer exacerbation from initiation to metastasis and invasion [31]. To further verify the occurrence of EMT, the migration and invasion of $B C$ cells were evaluated by wound healing and transwell assays. Results indicated that the abilities of cell migration and invasion 
were markedly enhanced in heat-treated BC cells compared with control BC cells (Fig. A-D). Addition of 3MA significantly depressed cell migration and invasion caused by heat treatment (Fig. 4A, B). Likewise, co-treatment with LY2109761 dramatically restrained migration and invasion caused by heat treatment in BC cells (Fig. 4C, D). Collectively, these results imply that autophagy induction and TGF- $\beta 2$ up-regulation, as well as the interaction between the two signaling pathway promotes EMT and enhances the abilities of migration and invasion in heat-treated BC cells.

\section{The PI3K/AKT/mTOR pathway is involved in heat treatment-induced autophagy in BC cells}

The PI3K/AKT/mTOR is one of the major upstream pathways of autophagy and involved in the regulation of autophagy [32]. Previous studies have shown that activation of mTOR inhibits autophagy and pharmacological mTOR inhibitors activates autophagy in model systems [33,34]. The AMPK pathway is another upstream pathway of autophagy and was reported to positively modulate autophagy in cancer cells [34]. Our results revealed that heat treatment decreased phosphorylations of AKT, mTOR and S6K1 which is a key downstream effector of mTOR, and augmented phosphorylation of AMPK, in a time-dependent manner (Fig. 5A). Heat treatment-induced the reduction of AKT phosphorylation was retarded by co-treatment with 740Y-P, a PI3K/AKT/mTOR pathway activator, which was accompanied by the inhibition of heat-induced autophagy as indicated by the attenuation of LC3- $\triangle$ accumulation, p62 reduction and LC3-囚puncta increase, as well as a down-regulation of mesenchymal markers $\mathrm{N}$-cadherin, Snail and MMP-9, and a up-regulation of epithelial marker E-cadherin (Fig. 5B-D). The data signify that heat treatment induced autophagy and consequent EMT occurrence in BC cells depend at least partially on the inhibition of the PI3K/AKT/mTOR pathway.

\section{Suppressing heat-induced autophagy facilitates apoptosis and depresses proliferation in $\mathrm{BC}$ cells}

Accumulating evidence indicate that autophagy can serves a cytoprotective role particularly in cancer treatment, and autophagy inhibition can enhance therapy-induced cell death or apoptosis [35, 36]. To determine the biological role of autophagy in heat-induced apoptosis, the autophagy inhibitor 3-MA was used to repress autophogosome formation and the block autophagy induced by heat treatment. To this end, BC cells were treated with 3-MA, heat exposure or both in combination. As shown in Fig. 6A-C, cotreatment with 3-MA further reduced cell viability rates at fifth day after heat treatment, and further raised heat treatment induced cell apoptotic rates. The cells co-treated with 3-MA exhibited more significant apoptotic morphological feature such as chromation condensation and nulear fragmentation with enhanced bright blue fluorescence (Fig. 6D). In consistent with the observations, heat treatment-induced the expression of cleaved-PARP and -caspase 9 were further augmented in the presence of 3-MA (Fig. 6E). Heat treatment induced elevation of Bax expression and reduction of $\mathrm{Bcl}-\mathrm{x} 1$ expression were intensified by 3-MA (Fig. 6E). In addition, co-treatment with 3-MA depressed the heat treatment-induced potentiation 
of cell proliferation (Fig. 6F). All these results illustrate that autophagy has a protective function against the heat treatment-induced apoptosis, thereby promoting cell proliferation.

\section{Autophagy inhibitor potentiates the antitumor effect of heat treatment and suppresses heat treatment- promoted metastasis in BC cells}

To evaluate the effect of sublethal heat treatment on tumor growth and determine whether autophagy inhibitor can enhance the antitumor effect of heat treatment in vivo, we established a xenograft tumor model of MDA-231 cells and examine the effect of vehicle, $C Q$, heat treatment alone, and a combination of heat treatment and CQ on tumor growth in nude mice. By the end of in vivo experiment, no significant difference in tumor volumes and weights was found between mice treated with vehicle and mice treated with CQ alone. Tumor growth was moderately inhibited by heat treatment alone. However, a significant growth inhibition was observed by the combination treatment (Fig. 7A-C). Western blotting of tumor samples showed that combination treatment increased heat treatment-induced the accumulation of LC3$\triangle$ and cleaved-caspase 9 , and attenuated heat treatment-induced down-regulation of E-cadherin and upregulation of $\mathrm{N}$-cadherin (Fig. 7D). The similar results were seen by immunohistochemistry analysis of tumor samples (Fig. 7E). These data were consistent with the results in vitro and further confirm that autophagy inhibitor can enhance the antitumor effect of heat treatment.

To determine the effect of heat treatment and CQ on the in vivo metastasis of MDA-231 cells, a tail vein metastasis assay was applied. As Fig. 7F shown, the number of the metastatic foci in the lung significantly increased in mice receiving heat treated-MDA-231 cells compared with those receiving $37^{\circ} \mathrm{C}$ treated-MDA-231 cells, co-treatment with CQ markedly decreased the number of metastatic foci in lung. The results indicate that sublethal heat treatment promoted distant metastasis of $\mathrm{BC}$ cells, which can be inhibited by suppressing autophagy.

\section{Discussion}

The aggressive local recurrence and accelerated distant metastasis of residual tumor cells after insufficient thermal ablation is a major impediment to cure solid tumor using the ablation techniques. Therefore, the molecular mechanisms underlying the biological behaviors need to be investigated in depth. In the present study, we treated BC cells with sublethal heat exposure to simulate the insufficient MWA. Results found that BC cells showed a reduction of viability and induction of apoptosis in the initial time after heat treatment, whereas the survived cells upon heat treatment exhibit a raised proliferation ability in the later stage. We demonstrate that sublethal heal treatment induced autophagy in BC cells in a temperature- and time-dependent manner, which was similar to previous finding in HCC cells $[14,20]$. Importantly, the depression of autophagy by 3-MA suppressed heat treatment-induced increase of TGF- $\beta 2$ expression and Smad2 phosphorylation, and enhancement of EMT, thereby inhibiting the induction of migration and invasion in $\mathrm{BC}$ cells after heat treatment. Thus, these data indicate that autophagy plays a central role in the migration and invasion of BC cells caused by inducing TGF- $\beta 2 / S m a d 2$ mediated EMT under sublethal heat treatment. 
Autophagy is an evolutionarily conserved lysosome-mediated degradation pathway by which cell selfdigest selected cellular macromolecules maintain homeostasis [36]. EMT, a switching process from the epithelial phenotype of an adherent cell to a motile mesenchymal phenotype is known to facilitate cancer metastasis and invasion in several human cancer [37]. It has been found that EMT signaling pathway can trigger or repress autophagy. Significantly, autophagy is also involved in the induction and inhibition of EMT. On the one hand, EMT requires autophagy to support the viability of potential metastasis of cancer cells [38]. On the other hand, increasing additional evidence indicates that autophagy acts to prevent EMT, and the activation of the autophagy may abate the acquisition of the EMT phenotype in cancer cells [39]. Therefore, autophagy plays dual effect on EMT in the development and progression of cancers, which dependent on the type of cancer or stimulation, and cellular context. Moreover, there is a interaction between autophagy and EMT [22]. In the present study, we showed that heat treatment induced autophagy triggered EMT by activating TGF- $\beta 2 /$ Smad signaling. We discovered the effect of heat treatment-induced autophagy on the migration and invasion of $\mathrm{BC}$ cells. We further explored the underlying mechanism. Autophagy promoted the migration and invasion of $\mathrm{BC}$ cells by triggering EMT. Next, by applying pharmacological autophagy inhibitor and TGF- $\beta 2$ receptor inhibitor, we demonstrated that autophagy up-regulated TGF- $\beta 2$ expression, and the TGF- $\beta 2 /$ Smad 2 signaling plays an important role in mediating autophagy-induced EMT. On the other hand, we revealed that autophagy-induced TGF$\beta 2$ could promote autophagy in turn. Autophagy and TGF- $\beta 2$ can thus form a positive feedback loop to synergistically facilitate the migration and invasion of $\mathrm{BC}$ cells. These finding also demonstrate that the migration and invasion of $\mathrm{BC}$ cells promoted by autophagy under heat treatment is dependent on TGF$\beta 2 /$ Smad2 signaling. TGF- $\beta$ is considered to be a master regulator of EMT in carcinoma [40]. It has been observed that cancer cells exposed to TGF- $\beta$ can result in a strong activation of autophagy. This effect is primarily facilitated by Smad signaling. However, TGF- $\beta$ can probably trigger both pro-tumorigenic and anti-tumorigenic signal and choice may be completely dependent on the cellular context and the stage of tumor progression [41]. But at least in the present model, autophagy up-regulated TGF- $\beta 2$ facilitated migration and invasion of BC cells by mediating EMT under heat treatment.

Autophagy is regulated by various signaling pathways. Previous studies reported that heat treatment induced autophagy is activated by the ATP/AMPK/mTOR pathway. Heat treatment reduced ATP levels, leading to an increase in AMP/ATP ratio and, ultimately, activation of the AMPK/mTOR pathway and autophagy induction in HCC cells [20]. Our results also showed an augmentation of AMPK phosphorylation upon heat treatment. Meanwhile, we found that heat treatment repressed phosphorylation of AKT, mTOR and S6K1. Pharmacological the PISK/AKT/mTOR pathway activator reversed the decrease of AKT phosphorylation level, retarded autophagy induction and EMT by heat treatment, proving that the $\mathrm{PI} 3 \mathrm{~K} / \mathrm{AKT} / \mathrm{mTOR}$ pathway negatively regulate heat-induced autophagy.

In the present study, another important finding is that inhibition of autophagy by 3-MA promoted apoptosis and repressed proliferation in BC cells under heat treatment. The findings supported heat treatment induced autophagy played a protective role to apoptotic cell death under this condition. It is known that interaction among various components of the autophagy and apoptosis pathways result in a complex crosstalk between the two, which is often induced by similar stimuli [42]. For instance, studies 
show that both autophagy and apoptosis are activated in response to metabolic stress. Growth factor deprivation activate the LKB1-AMPK pathway, thereby increasing stability of cyclin-dependent kinase inhibitor $\mathrm{P} 27^{\mathrm{kip} 1}$ and thus promoting cell survival through induction of autophagy. Conversely, knockdown of P27 ${ }^{\mathrm{kip} 1}$ under these conditions activates apoptosis [43]. For another instance, ATG5, which is required for the formation of autophagasomes, also enhances susceptibility to apoptotic stimuli upon cleavage by caspase. Noteworthy, caspase-mediated cleavage of ATG5 and Beclin 1 switches autophagy to apoptosis, while cleavage of ATG4D results in a truncated product with increased autophagic activity [44]. In the present model, the precise mechanism underlying the facilitation of apoptosis by autophagy inhibition need to be further investigated.

In addition, our in vivo mouse model experiments also confirmed the results of in vitro cell model. We showed that heat treatment induced autophagy and activated EMT in MDA-231 cell xenograft tumor, and inhibition of autophagy by CQ markedly restrained tumor growth via depressing EMT and promoting apoptosis. The tail vein metastasis assay also indicated that BC cells after heat treatment exhibited potentiated pulmonary metastasis ability, which could be notably suppressed by CQ treatment.

\section{Conclusions}

Our data demonstrated that sublethal heat treatment induced autophagy which triggered TGF- $\beta /$ Smad2 mediated EMT, thereby promoting migration and invasion in the $\mathrm{BC}$ cells. In line with these findings, the inhibition of autophagy could enhance the anti-BC effect of heat treatment and repressed heat treatment caused the potentiation of metastatic ability in BC cells. Therefore, suppressing autophagy might be a novel strategy for overcoming insufficient MWA ablation caused progression and metastasis of residual $\mathrm{BC}$ cells.

\section{Abbreviations}

$\mathrm{BC}$

breast cancer

MWA

microwave ablation

VEGF

vascular endothelial growth factor

MMP

matrix metalloproteinase

PCNA

proliferating cell nuclear antigen

CQ

chloroquine

3-MA

methyladenine 
EMT

epithelial-mesenchymal transition

CCK-8

cell counting kit-8

LC3

microtubule-associated protein 1 light chain 3

TGF- $\beta$

transforming growth factor- $\beta$

PARP

poly (ADP-ribose) polymerase

AVOs

acidic vascular organelles

MDC

monodansylcadaverine

AMPK

adenosin 5'-monophosphat-activated protein kinase

PI3K

phosphatidylinositol3'-kinase

AKT

protein kinase $B$

mTOR

mammalian target of rapamycin

\section{Declarations}

\section{Acknowledgements}

Not applicable

\section{Author Contribution}

Z-NL, CL and HY designed the study, conducted the data analysis and drafted the manuscript. Z-NL, F-LW, H-WG, Z-PW and PZ performed the experiments and data process. CL, HY and JL revised and edited the manuscript. CL reviewed the manuscript and supervised the project. All authors read and approved the final manuscript.

\section{Funding}

This work was supported by the National Nature Science Foundation of China (Grant No. 81402172).

\section{Availability of data and materials}

The datasets analyzed in this study are available from the corresponding author on reasonable request. 


\section{Declarations}

\section{Ethics approval and consent to participate}

All the animal experiments were performed in accordance with the guidelines approved by the the Institutional Animal Care and Use Committee of the Jiangsu University and extensive efforts were made to minimize the suffering of animals.

\section{Consent for publication}

Not applicable

\section{Competing Interests}

The authors declare that they have no competing interests.

\section{Author details}

${ }^{1}$ Department of Breast Surgery, The Affiliated Obstetrics and Gynecology Hospital of Nanjing Medical University, Nanjing Maternity and Child Health Care Hospital, Nanjing 210000, Jiangsu, China.

${ }^{2}$ Department of Pulmonary Medicine, Affiliated Hospital of Jiangsu University, Zhenjiang 212001, Jiangsu, China.

\section{References}

1. Bray F, Ferlay J, Soerjomataram J, Siegel RL, Torre LA, Jemal A. Global cancer statistics 2018: GLOBOCAN estimates of incidence and mortality worldwide for 36 cancer in 185 countries. CA: Cancer J Clin. 2018;68:394-424.

2. Fleming MM, Holbrook Al, Newell MS. Update on image-guided percutaneous ablation of breast cancer. AJR. 2017;208:267-74.

3. Peek MCL, Douek M. Ablative techniques for the treatment of benign and malignant breast tumors. J Ther Ultrasound. 2017;5:18.

4. Brem RF. Radiofrequency ablation of breast cancer: A step forward. Radiology. 2018;289:325-6.

5. Peek MCL, Ahmed M, Napoli A, Usiskin S, Baker R, Douek M. Minimally invasive ablative techniques in the treatment of breast cancer: a systematic review and meta-analysis. Int J Hyperthermin. 2017;33:191-202.

6. Roubidoux MA, Yang W, Stafford RJ. Image-guided ablation in breast cancer treatment. Tech Vasc Interv Radiol. 2014;17:49-54.

7. Yu J, Han Z-Y, Li T, Feng W-Z, Y X-L, LuoY-C, et al. Microwave ablation versus nipple sparing mastectomy for breast cancer $\leq 5 \mathrm{Cm}$ : A pilot cohort study. Front Oncol. 2020;10:546883. 
8. Yu J, Liang P, Yu X, Liu F, Chen L, Wang Y. A comparison of microwave ablation and bipolar radiofrequency ablation both with an internally cooled probe: results in ex vivo and in vivo porcine livers. Eur J Radiol. 2011;79:124-30.

9. Zhou W, Zha X, Liu X, Ding Q, Chen L, Ni Y, et al. US-guided percutaneous microwave coagulation of small breast cancers: a clinical study. Radiology. 2012;263:364-73.

10. Zhou W, Jiang Y, Chen L, Ling L, Liang M, Pan H, et al. Image and pathological changes after microwave ablation of breast cancer: a pilot study. Eur J Radiol 2014;83:1771-7.

11. Zhou W, Ding Q, Liu X, Jiang Y, Chen L, Zhang Y, et al. Percutaneous microwave coagulation for eradication of VX2 tumor subcutaneously in rabbits. Would J Surg Oncol. 2012;10:97.

12. Song $X$, Liang $M$, Zhou W, Ren L, Liu Z, Wang G, et al. Doxorubin hydrochloric increases tumor coagulation and end-point survival in percutaneous microwave ablation of tumours in a VX2 rabbit tumour model. Int J Hyperthermia. 2016;32:265-71.

13. Liu Z, Dai H, Jia G, Li Y, Liu X, Ren W, et al. Insufficient radio frequency ablation promotes human hepatoma SMMC 7721 cell proliferation by stimulating vascular endothelial growth factor overexpression. Oncol Lett. 2015;9:1893-6.

14. Zhao Z, Wu J, Liu X, Liang M, Zhou X, Ouyang S, et al. Insufficient radiofrequency ablation promotes proliferation of residual hepatocellular carcinoma via autophagy. Cancer Lett. 2018;421:73-81.

15. Medhat E, Abdel AA, Nabeel M, Elbaz T, Zakaria Z, Shousha $H$, et al. Value of microwave ablation in treatment of large lesions of hepatocellular carcinoma. J Digestive Dis. 2015;16:456-63.

16. Yu H, Burke C. Comparison of percutaneous ablation technologies in the treatment of malignant liver tumors. Semin Intervent Radiol. 2014;31:129-37.

17. Ke S, Ding XM, Kong J, Wang SH, Cheng Y, Sun WB. Low temperature of radiofrequency ablation at the target sites can facilitate rapid progression of residual hepatic VX2 carcinoma. J Transl Med. 2018;8:73.

18. Dong S, Kong J, Kong F, Kong J, Gao J, Ke S, et al. Insufficient radiofrequency ablation promotes epithelial-mesenchymal transition of hepatocellular carcinoma cells through AKT and ERK signaling pathway. J Transl Med. 2013;11:273.

19. Yoshida S, Korbek M, Ikenaga N, Schmelzle M, Masuzaki R, Csizmadia, et al. Sublethal heat treatment promotes epithelial-mesenchymal transition and enhances the malignant potential of hepatocellular carcinoma. Hepatology. 2013;58:1667-80.

20. Jiang J, Chen S, Li K, Zhang C, Tan Y, Deng Q, Chai Y, et al. Targeting autophagy enhances heat stress-induced apoptosis via the ATP-AMPK-mTOR axis for hepatocellular carcinoma. Int $\mathrm{J}$ Hyperthermia. 2019;36:498-509.

21. Kong P, Pan H, Yu M, Chen L, Ge H, Zhu J, et al. Insufficient microwave ablation-induced promotion of distant metastasis is suppressed by $\beta$-catenin pathway inhibition in breast cancer. Oncotarget. 2017;8:115089-101.

22. Chen H-T, Liu H, Mao M-J, Tan Y, Mo X-Q, Meng X-J, et al. Crosstalk between autophagy and epithelial-mesenchymal transition and its application in cancer therapy. Mol Cancer. 2019;18:101. 
23. Gugnoni M, Sancisi V, Manzotti G, Gandolfi G, Ciarrocchi A. Autophagy and epithelial-mesenchymal transition: an intricate interplay in cancer. Cell Death Dis. 2016;7:e2520.

24. Chen $P$, Huang $H-P$, Wang $Y$, Jin J, Long W-G, Chen $K$, et al. Curcumin overcome primary gefitinib resistance in non-small-cell lung cancer cells through inducing autophagy-related cell death. J Exp Clin Cancer Res. 2019;38:254

25. Dai C-H, Shu Y, Chen P, Wu J-N, Zhu L-H, Yuan R-X, et al. YM155 sensitizes non-small cell lung cancer cells to EGFR-tyrosine kinase inhibitors through the mechanism of autophagy induction. BBA-Mol Basis Dis. 2018;1864:3786-98.

26. Xiang M, Jiang H-G, Shu Y, Chen Y-J, Jin J, Zhu Y-M. Bisdemethoxycurcumin enhances the sensitivity of non-small cell lung cancer cells to icotinib via dual induction of autophagy and apoptosis. Int $\mathrm{J}$ Biol Sci. 2020;16:1536-50.

27. Zhao Y, Gong S, Shunmei E, Zou J. Induction of macroautophagy by heat. Mol Biol Rep. 2009;36:2323-29.

28. Dash S, Sarashetti PM, Rajasheker B, Chowdhury R, Mukherjee S. TGF- $\beta 2$-induced EMT is dampened by inhibition of autophagy and TNF-a treatment. Oncotarget. 2018;9:6433-49.

29. Yang T, Huang T, Zhang D, Wang M, Wu B, Shang Y, et al. TGF- $\beta$ receptor inhibitor LY2109761 enhances the radiosensitivity of gastric cancer by inactivating the TGF/SMAD4 signaling pathway. Aging. 2019;11:8892-910.

30. Kim S, Lee J, Jeon M, Nam ST, Lee JE. Elevated TGF- $\beta 1$, and $-\beta 2$ expression accelerates the epithelial to mesenchymal transition in triple-negative breast cancer cells. Cytokine. 2015;75:151-8.

31. Saitoh M. Involvement of partial EMT in cancer progression. J Biochem. 2018;164:257-64.

32. Yang Z, Klionsky DJ. An overview of the molecular mechanism of autophagy. Current Top Microbiol Immunol. 2009;335:1-32.

33. Yang Z, Klionsky DJ. Mammalian autophagy: Core molecular machinery and signaling regulation. Curr Opin Cell Biol. 2010;22:124-31.

34. Hay H, Sonenbery N. Upstream and downstream of mTOR. Genes Dev. 2004;18:1926-45

35. Amaravadi RK, Yu D, Lum JJ, Bui T, Christophorou MA, Evan GI, et al. Autophagy inhibition enhances therapy-induced apoptosis in a Myc-induced model of lymphama. J Clin Invest. 2007;117:326-36.

36. Ryter SW, Cloonan SM, Choi AM. Autophagy: a critical regulator of cellular metabolism and homeostasis. Mol cells. 2013;36:7-16.

37. Foroni C, Broggini M, General D, Damia G. Epithelial-mesenchymal transition and breast cancer: Role, molecular mechanisms and clinical impact. Cancer Treat Rev. 2012;38:689-97.

38. Singla M, Bhattacharyya S. Autophagy as a potential therapeutic target during epithelial to mesenchymal transition in renal cell carcinoma: An in vitro study. Biomed pharmacother. 2017;94:332-40.

39. Catalano M, D'Aessandro G, Lepore F, Corazzari M, Caldarola S, Valacca C, et al. Autophagy induction impairs migration and invasion by reversing EMT in glioblastoma cells. Mol Oncol. 2015;9:1612-25. 
40. Wendt MK, Allington TM, Schiemann WP. Mechanism of the epithelial-mesenchymal transition by TGF-beta. Future Oncol. 2009;5:1145-68.

41. Derynck R, Akhursk RT, Balmain A. TGF- $\beta$ signaling in tumor suppression and cancer progression. Nat Genet. 2001;29:117-29.

42. Maiuri MC, Zalckvar E, Kimchi A, Kroemer G. Self-eating: crosstalk between autophagy and apoptosis, Nat Rev Mol Cell Biol. 2009;8:741-52.

43. Liang J, Shao SH, Xu ZX, Hennessy B, Ding Z, Larrea M, et al. The energy sensing LKB1-AMPK pathway regulates p27 (kip1) phosphorylation mediating the decision to enter autophagy or apoptosis. Nat Cell Biol. 2007;9:218-24.

44. Yousefi S, Perozzo R, Schmid â⿴ , Ziemiecki A, Schaffner T, Scapozza L, et al. Calpain-mediated cleavage of Atg5 switches autophagy to apoptosis. Nat Cell Biol. 2006;8:1124-32.

\section{Figures}



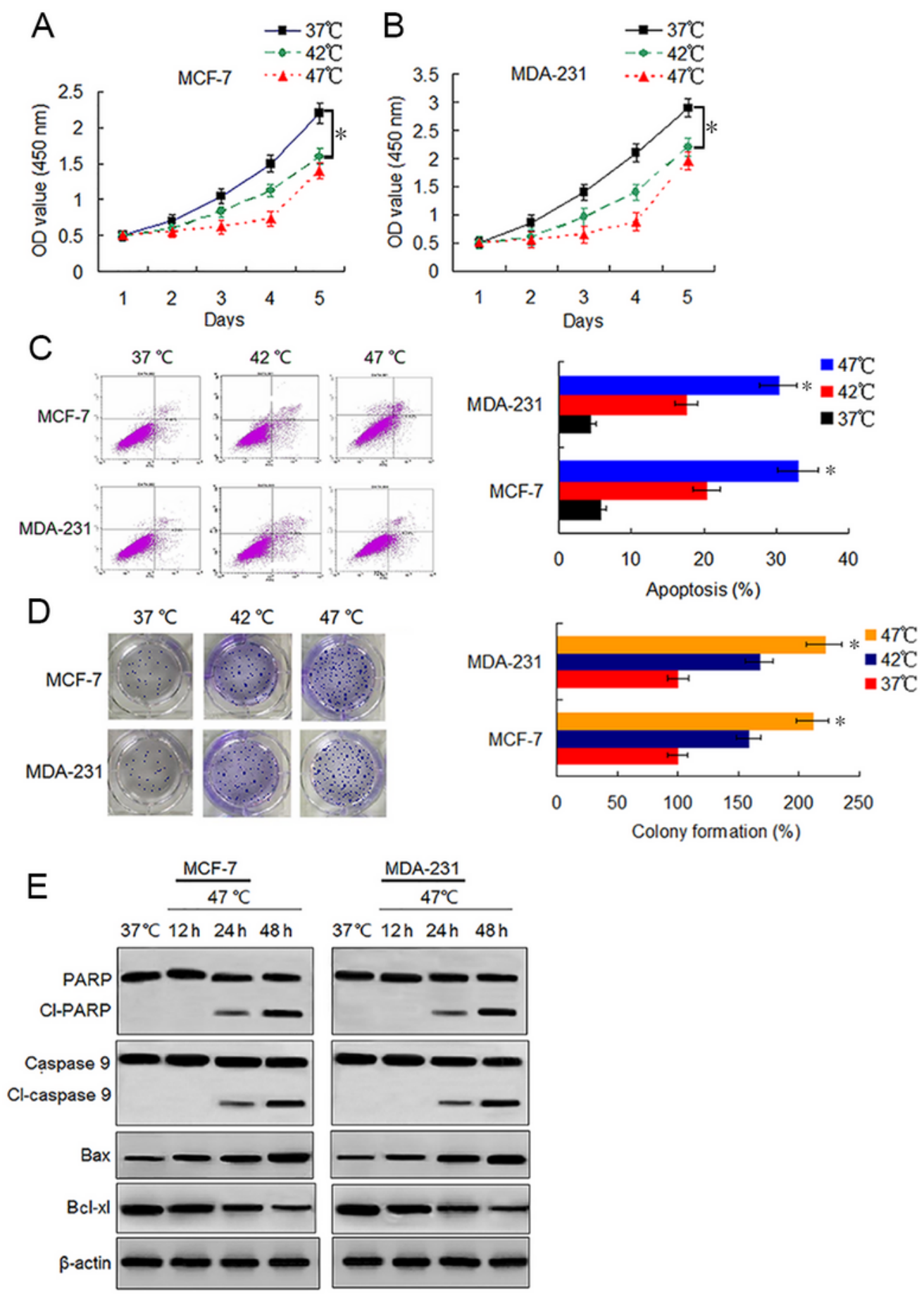

Fig. 1

\section{Figure 1}

Heat treat reduces viability and induces apoptosis but promotes proliferation of survived BC cells. A, B MCF-7 and MDA-231 cells were exposed to $42^{\circ} \mathrm{C}$ and $47^{\circ} \mathrm{C}$ for $30 \mathrm{~min}$, followed by culture at $37^{\circ} \mathrm{C}$ for 24 $h$, or maintained at $37^{\circ} \mathrm{C}$, then the viability rate of the cells were tested by CCK-8 assay $\left({ }^{\star} P<0.05\right)$. C MCF-7 and MDA-231 cells were treated as (A, B), and the apoptotic rate was analyzed by flow cytometry $\left({ }^{*} \mathrm{P}<0.05\right.$ vs $42^{\circ} \mathrm{C} ; \mathrm{P}<0.005$ vs $\left.37^{\circ} \mathrm{C}\right)$. D MCF-7 and MDA-231 cells were exposed to $42^{\circ} \mathrm{C}$ and $47^{\circ} \mathrm{C}$ for 
$30 \mathrm{~min}$, followed by culture at $37^{\circ} \mathrm{C}$ for $24 \mathrm{~h}$, or maintained at $37^{\circ} \mathrm{C}$, then continue to culture for 14 days, the colony formation abilities were assessed by clonogenic assay ( ${ }^{*} \mathrm{P}<0.01$ vs $42^{\circ} \mathrm{C} ; \mathrm{P}<0.001$ vs $37^{\circ} \mathrm{C}$ ). $E$ The two cell lines were treated as $(A, B)$, the expressions of the indicated proteins were detected by western blotting.

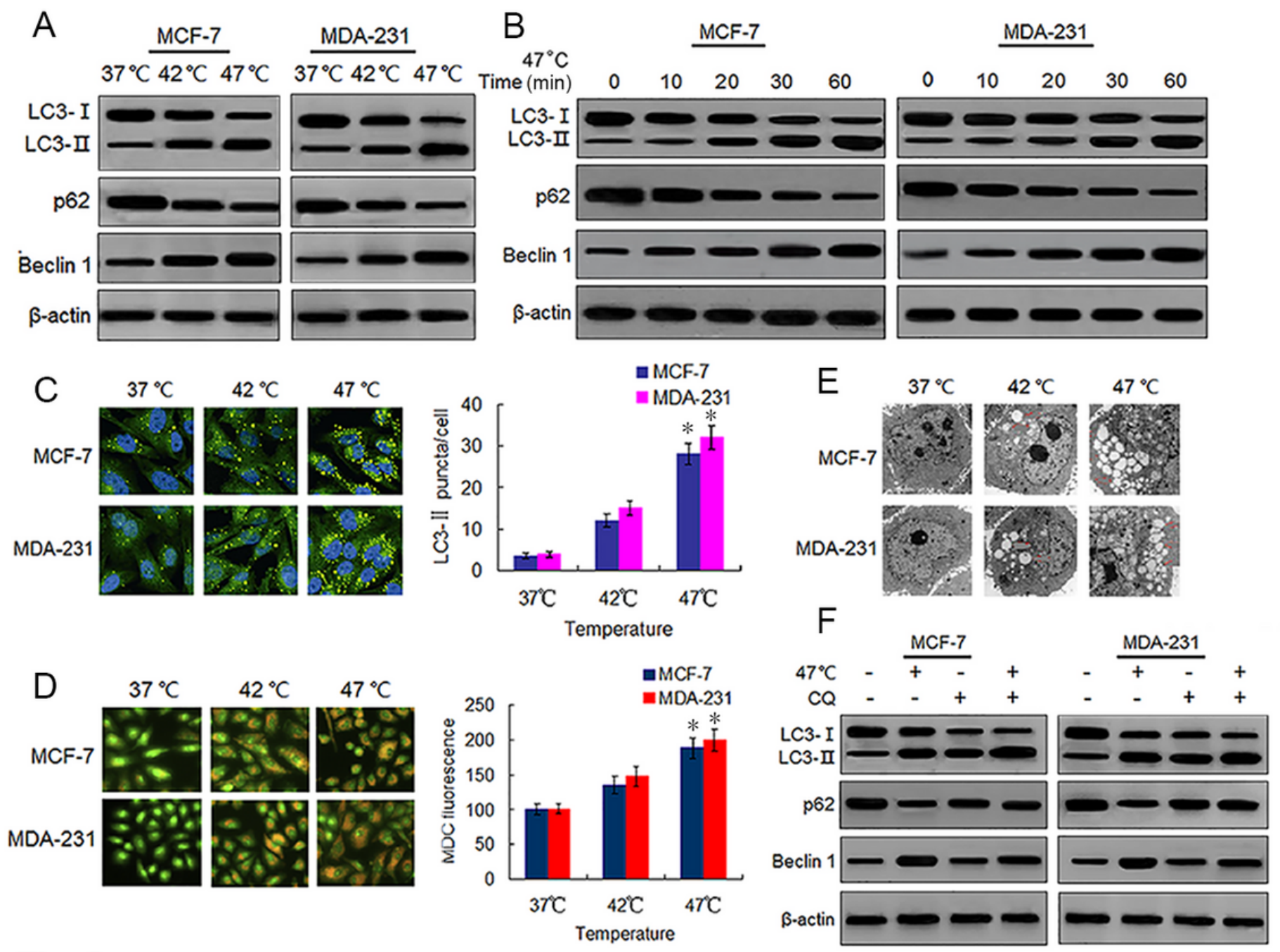

Fig. 2

\section{Figure 2}

Heat treatment induces autophagy in BC cells. A, B MCF-7 and MDA-231 cells were exposed to $42^{\circ} \mathrm{C}$ and $47^{\circ} \mathrm{C}$ for $30 \mathrm{~min}$, followed by incubation in $37^{\circ} \mathrm{C}$ for $24 \mathrm{~h}$, or maintained at $37^{\circ} \mathrm{C}(\mathrm{A})$, or to $47^{\circ} \mathrm{C}$ for 0,10 , $20,30,60 \mathrm{~min}$, followed by culture at $37^{\circ} \mathrm{C}$ for $24 \mathrm{~h}(\mathrm{~B})$, the expressions of the indicated proteins were analyzed by western blotting. C MCF-7 and MDA-231 cells were treated as (A, B), then LC3-区 puncta formation was detected using immunofluorescence analysis and imaged by confocal microscope (left). The number of LC3- $₫$ puncta/cell was quantified by Image-Pro plus 5.1 software (right) ( ${ }^{*} P<0.05$ vs $42^{\circ} \mathrm{C} ; \mathrm{P}<0.005$ vs $\left.37^{\circ} \mathrm{C}\right)$. $\mathrm{D}$ The two cell lines were treated as $(\mathrm{A}, \mathrm{B})$, then AVOs in cells were detected by MDC staining and imaged by a fluorescence microscope (left). The intensity of MDC fluorescence in control $\left(37^{\circ} \mathrm{C}\right)$ was defined as $100 \%\left({ }^{*} \mathrm{P}<0.05\right.$ vs $42^{\circ} \mathrm{C} ; \mathrm{P}<0.001$ vs $\left.37^{\circ} \mathrm{C}\right)$. E Transmission electron 
microscopy showed an increased number of autophagic vacuoles in MCF-7 and MDA-231 cells after exposure to $47^{\circ} \mathrm{C}$ for $30 \mathrm{~min}$. F MCF-7 and MDA-231 cells were exposed to $47^{\circ} \mathrm{C}$ for $30 \mathrm{~min}$ in the absence or presence of CQ $(10 \mu \mathrm{M})$, followed by culture at $37^{\circ} \mathrm{C}$ for $24 \mathrm{~h}$, the expressions of the indicated proteins were analyzed by western blotting.
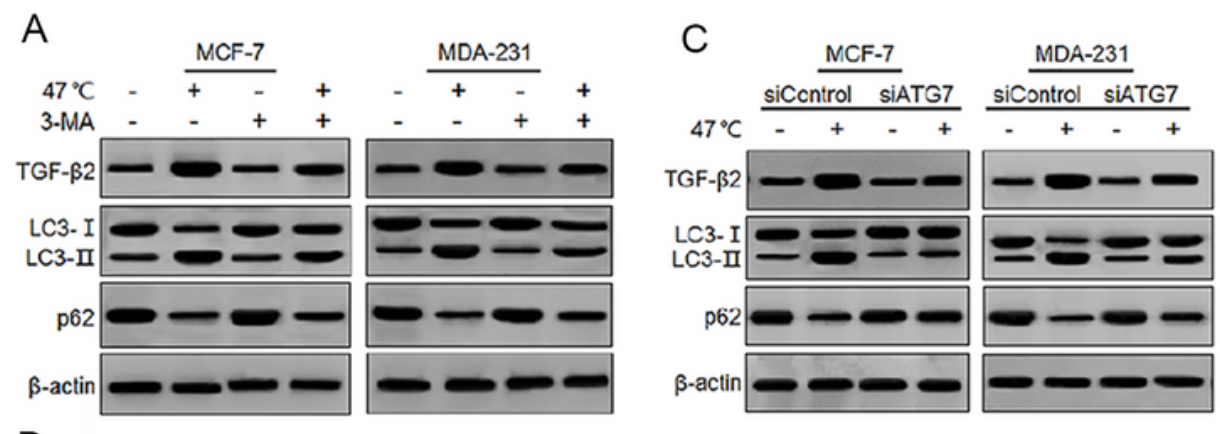
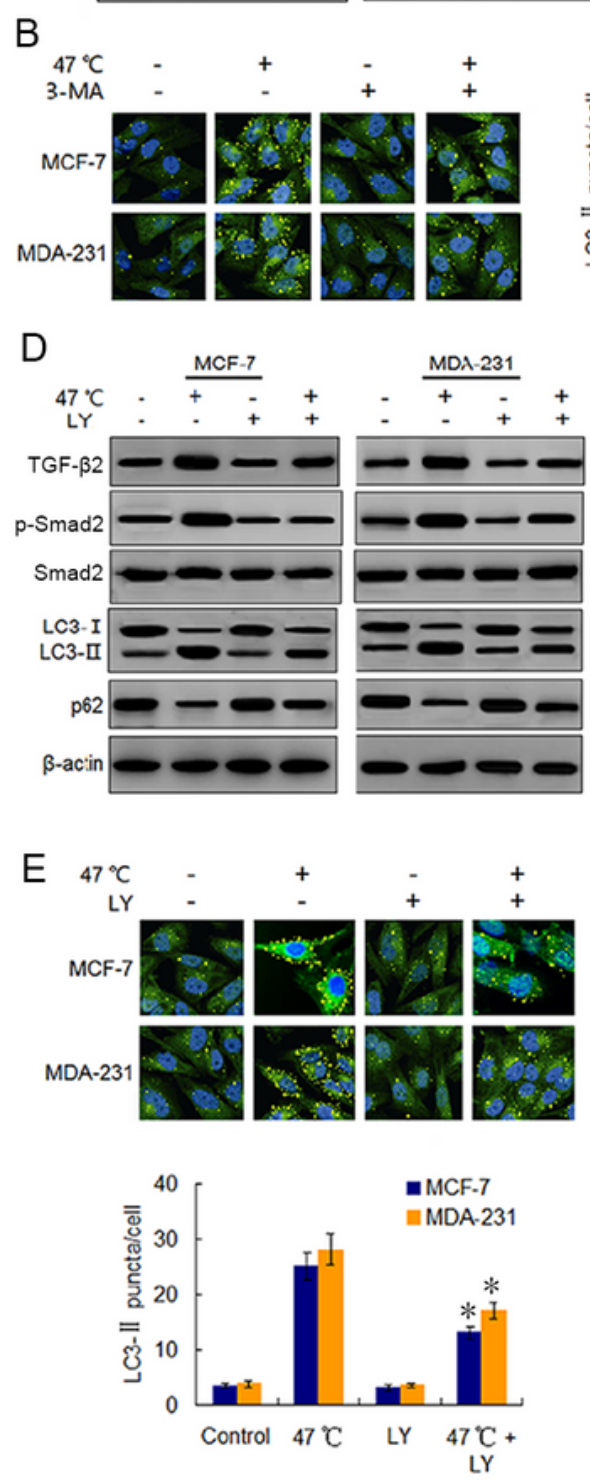

Fig. 3
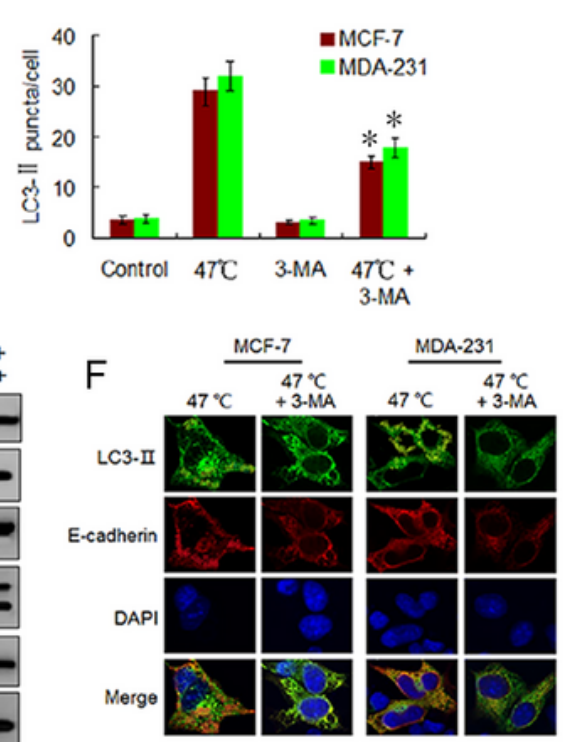

G

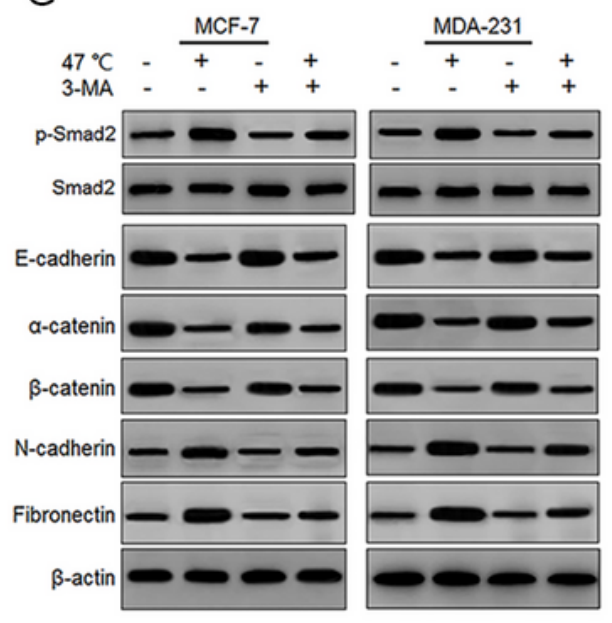

Figure 3 
Heat-induced autophagy promotes EMT in BC cells by up-regulating TGF- $\beta 2$. A MCF-7 and MDA-231 cells were exposed to $47^{\circ} \mathrm{C}$ for $30 \mathrm{~min}$ in the absence or presence of 3-MA $(10 \mu \mathrm{M})$, followed by culture at $37^{\circ} \mathrm{C}$ for $24 \mathrm{~h}$, or maintained at $37^{\circ} \mathrm{C}$. Then expressions of the indicated proteins were analyzed by western blotting. B MCF-7 and MDA-231 cells were treated as (A), the LC3- $₫$ puncta formation was determined using immunofluorescence analysis and imaged by confocal microscope (left). The number of LC3- $\$ puncta/cell was quantified by Image-Pro plus 5.1 software (right) $\left({ }^{*} \mathrm{P}<0.01\right.$ vs $\left.47^{\circ} \mathrm{C}\right)$. C After transfection with siATG7 or siControl, MCF-7 and MDA-231 cells were exposed to $47^{\circ} \mathrm{C}$, followed by culture at $37^{\circ} \mathrm{C}$ for $24 \mathrm{~h}$, or maitained at $37^{\circ} \mathrm{C}$ (control). The expressions of the indicated proteins were analyzed by western blotting. D The two cell lines were exposed to $47^{\circ} \mathrm{C}$ for $30 \mathrm{~min}$ in the absence or presence of LY2109761 $(20 \mu \mathrm{M})$, or maintained at $37^{\circ} \mathrm{C}$, the expressions of the indicated proteins were analyzed by western blotting. E The two cell lines were treated as (D), the LC3-囚 puncta formation was determined using immunofluorescence analysis and imaged by confocal microscope (upper). The number of LC3-邓 puncta/cell was quantified by Image-Pro plus 5.1 Software (lower) ( ${ }^{*} \mathrm{P}<0.05$ vs $47^{\circ} \mathrm{C}$ ). $\mathrm{F}$

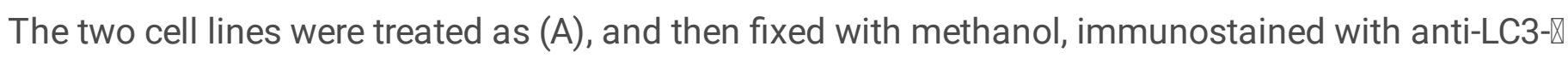
(green), anti-E-cadherin (red) and DAPI (blue) bodies, and observed by confocal microscope to show the intracellular co-localization of LC3- $₫$ and E-cadherin. G MCF-7 and MDA-231 cells were treated as (A), the expressions of the indicated proteins were analyzed by western blotting. 


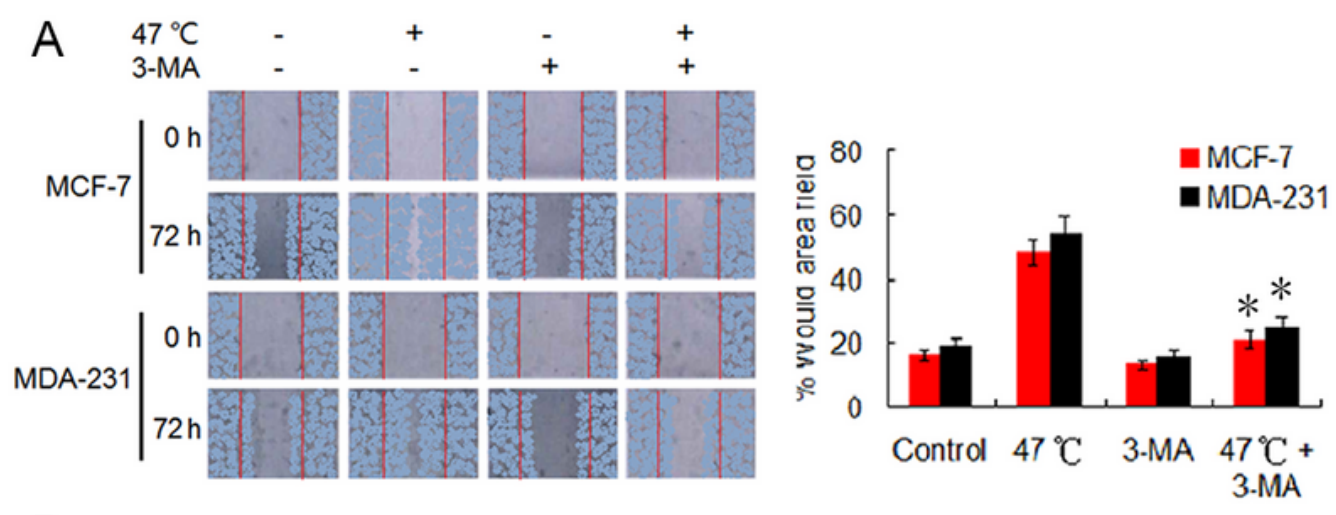

B
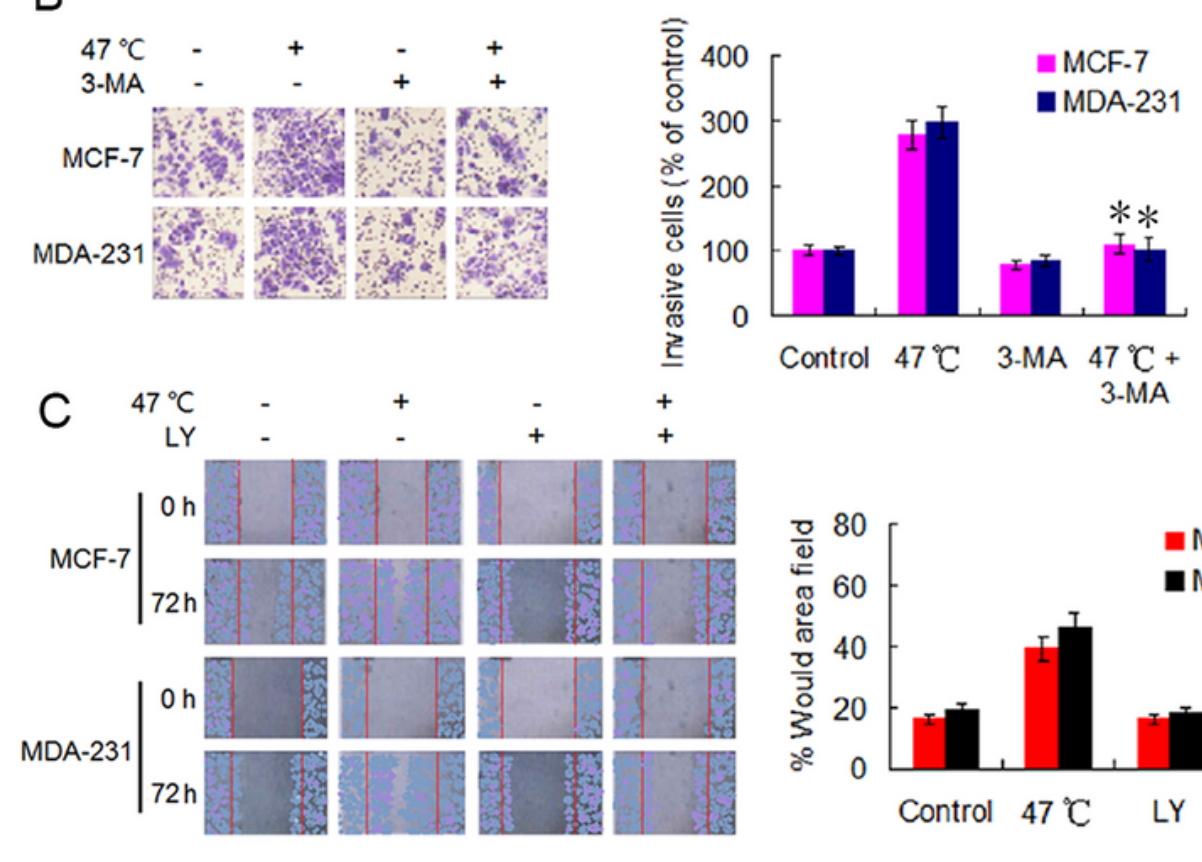

D

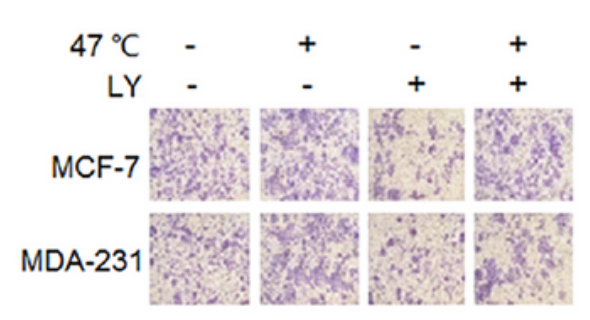

Fig. 4

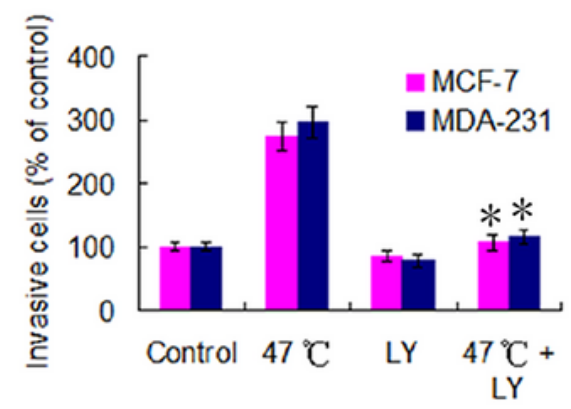

\section{Figure 4}

Heat treatment enhances the abilities of migration and invasion via TGF- $\beta 2$ mediated EMT. A MCF-7 and MDA-231 were exposed to $47^{\circ} \mathrm{C}$ for $30 \mathrm{~min}$ in the absence or presence of 3-MA $(10 \mu \mathrm{M})$, followed by culture at $37^{\circ} \mathrm{C}$ for $24 \mathrm{~h}$, or maintained at $37^{\circ} \mathrm{C}$, then cell migration ability was measured using the wound-healing assay. Images were acquired immediately $(0 \mathrm{~h})$ and at $72 \mathrm{~h}$ after wounding. Wound closure was analyzed in five random fields by Image $\mathrm{J}$ Software to calculate the percentage of wound 
area filled $\left({ }^{*} P<0.01\right.$ vs $\left.47^{\circ} \mathrm{C}\right)$. B MCF-7 and MDA-231 cells were treated as (A), cell invasion ability was measured using the transwell invasion assay. The invaded cells were counted in five randomly selected area under high magnification microscope $(200 \times)$. The quantification of invaded cells was defined as $100 \%$ in control $\left(37^{\circ} \mathrm{C}\right)\left({ }^{*} \mathrm{P}<0.001\right.$ vs $\left.47^{\circ} \mathrm{C}\right)$. C The two cell lines were exposed to $47^{\circ} \mathrm{C}$ for $30 \mathrm{~min}$ in the absence or presence of LY2109761 $(20 \mu \mathrm{M})$, followed by culture at $37^{\circ} \mathrm{C}$ for $24 \mathrm{~h}$, or maintained at $37^{\circ} \mathrm{C}$, then cell migration ability was measured using the wound-healing assay ( ${ }^{*} \mathrm{P}<0.01$ vs $47^{\circ} \mathrm{C}$ ). $\mathrm{D}$ The two cell lines were treated as (C), cell invasion ability was measured using transwell invasion assay $\left({ }^{\star} \mathrm{P}<\right.$ 0.001 vs $\left.47^{\circ} \mathrm{C}\right)$. 
A

Tem $37^{\circ} \mathrm{C} \frac{\text { MCF-7 }}{47^{\circ} \mathrm{C}} \quad 37^{\circ} \mathrm{C} \frac{\text { MDA-231 }}{47^{\circ} \mathrm{C}}$

$\begin{array}{lllllllll}\text { Time(min) } & 60 & 10 & 30 & 60 & 60 & 10 & 30 & 60\end{array}$
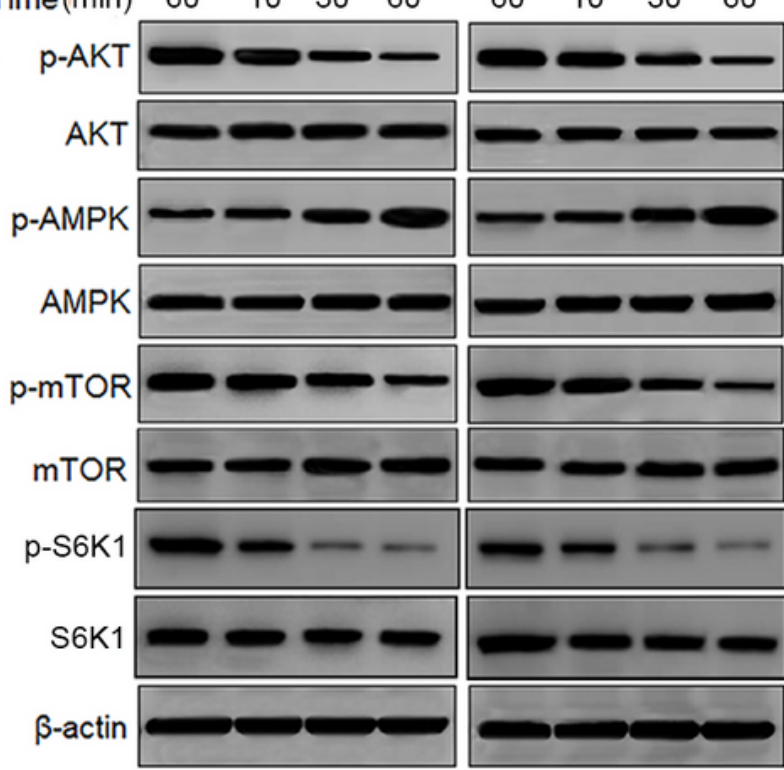

C
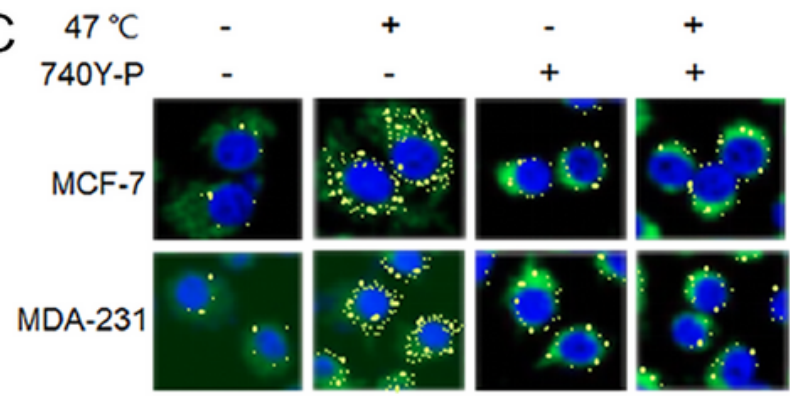

D
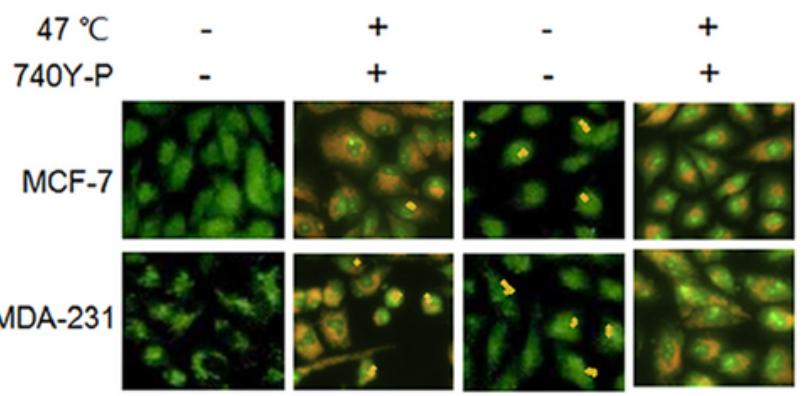

B
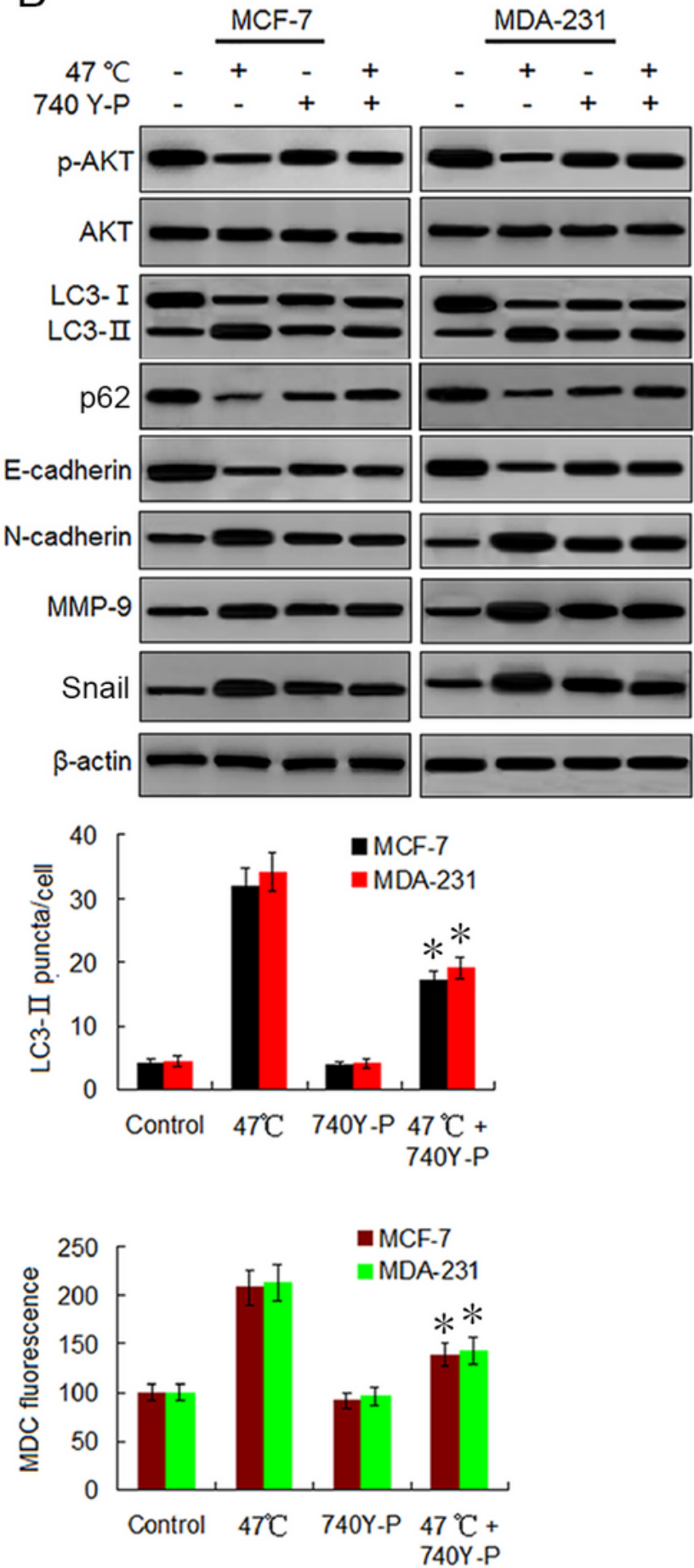

Fig. 5

\section{Figure 5}

The AKT/mTOR signaling pathway is involved in heat-induced autophagy in BC cells. A MCF-7 and MDA231 cells were exposed to $47^{\circ} \mathrm{C}$ for $10,30,60 \mathrm{~min}$, or to $37^{\circ} \mathrm{C}$ for $60 \mathrm{~min}$, followed by culture at $37^{\circ} \mathrm{C}$ for $24 \mathrm{~h}$. The expressions of the indicated proteins were analyzed by western blotting. B MCF-7 and MDA-231 cells were exposed to $47^{\circ} \mathrm{C}$ for $30 \mathrm{~min}$ in the absence or presence of 740Y-P $(20 \mu \mathrm{g} / \mathrm{ml})$, followed by culture at $37^{\circ} \mathrm{C}$ for $24 \mathrm{~h}$. The expressions of indicated proteins were analyzed by western blotting. C The 
two cell lines were treated as (B), then the LC3- $\$ puncta formation was determined using

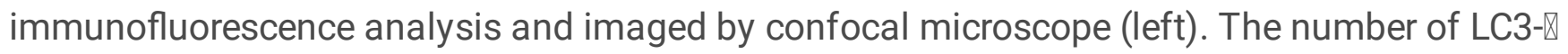
puncta/cell was quantified by Imaged-Pro plus 5.1 software (right) $\left({ }^{*} \mathrm{P}<0.01 \mathrm{vs} 47^{\circ} \mathrm{C}\right)$. D The two cell lines were treated as $(B)$, then AVOs were determined by MDC staining and imaged by a fluorescence microscope. The intensity of MDC fluorescence in control $\left(37^{\circ} \mathrm{C}\right)$ as defined as $100 \%\left({ }^{\star} \mathrm{P}<0.01\right.$ vs $\left.47^{\circ} \mathrm{C}\right)$.
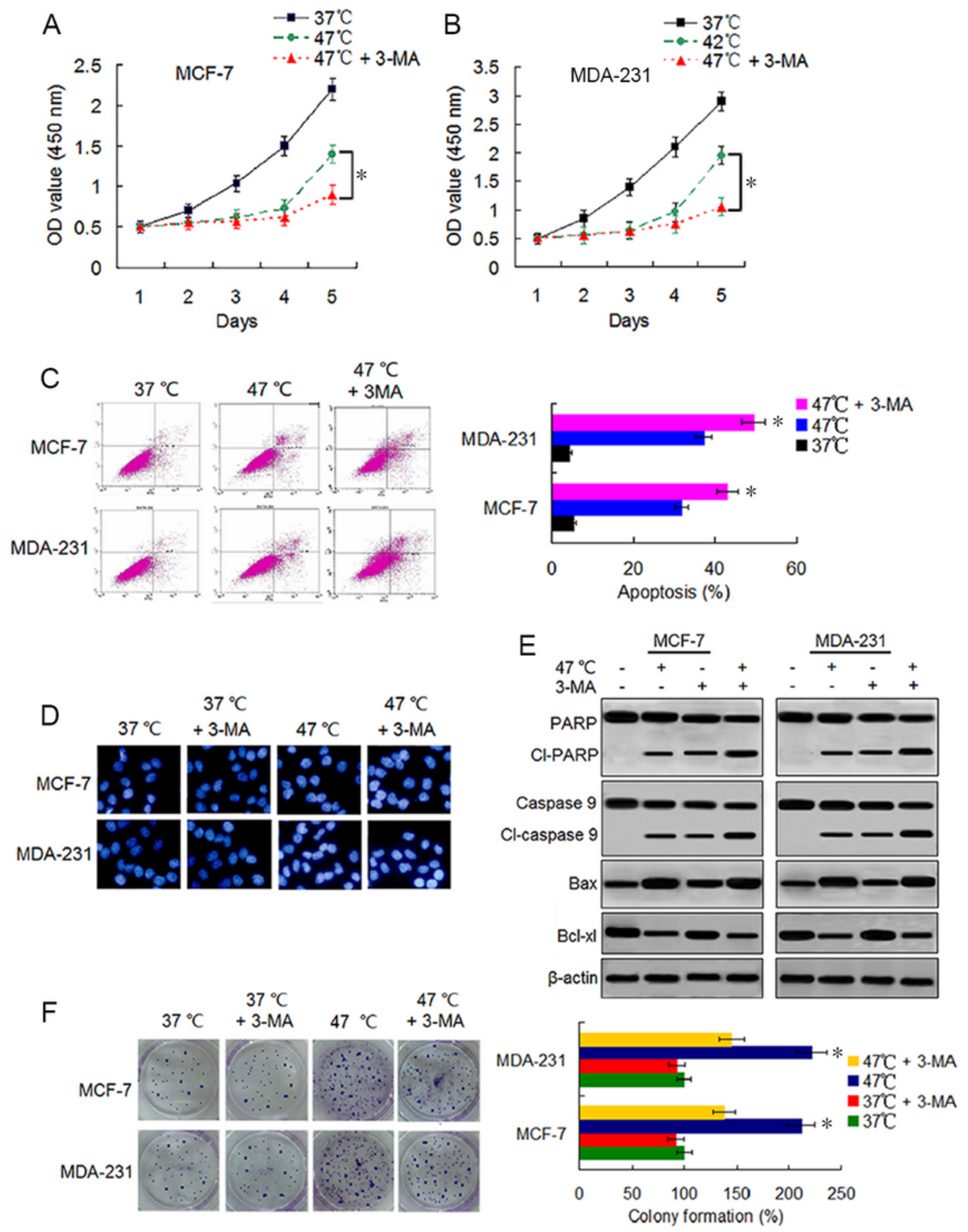

Fig. 6

\section{Figure 6}


Suppressing heat-induced autophagy facilitates apoptosis and depresses proliferation in $B C$ cells. $A, B$ MCF-7 and MDA-231 cells were exposed to $47^{\circ} \mathrm{C}$ for $30 \mathrm{~min}$ in the absence or presence of 3-MA $(10 \mu \mathrm{M})$, or maintained at $37^{\circ} \mathrm{C}$ as control, followed by culture at $37^{\circ} \mathrm{C}$ for $24 \mathrm{~h}$. The viability rate of the cells was detected by CCK-8 assay ( $\left.{ }^{*} P<0.05\right)$. C MCF-7 and MDA-231 cells were treated as $(A, B)$, and the apoptotic rate was analyzed by flow cytometry ( ${ }^{\star} \mathrm{P}<0.05$ vs $42^{\circ} \mathrm{C} ; \mathrm{P}<0.001$ vs $\left.37^{\circ} \mathrm{C}\right)$. $\mathrm{D}$ The two cells lines were exposed to $37^{\circ} \mathrm{C}$ or $47^{\circ} \mathrm{C}$ for $30 \mathrm{~min}$ in the absence or presence of 3-MA $(10 \mu \mathrm{M})$, then stained by Hoechst 33258 and imaged using fluorescence microscope. E The two cell lines were treated as (D), the expressions of the indicated proteins were analyzed by western blotting. $\mathrm{F}$ The two cell lines were exposed to $37^{\circ} \mathrm{C}$ or $47^{\circ} \mathrm{C}$ for $30 \mathrm{~min}$ in the absence or presence of 3-MA $(10 \mu \mathrm{M})$, followed by culture at $37^{\circ} \mathrm{C}$ for 14 days, colony formation abilities were assessed by clonogenic assay ( ${ }^{*} \mathrm{P}<0.01$ vs $47^{\circ} \mathrm{C}+3-$ $M A)$.
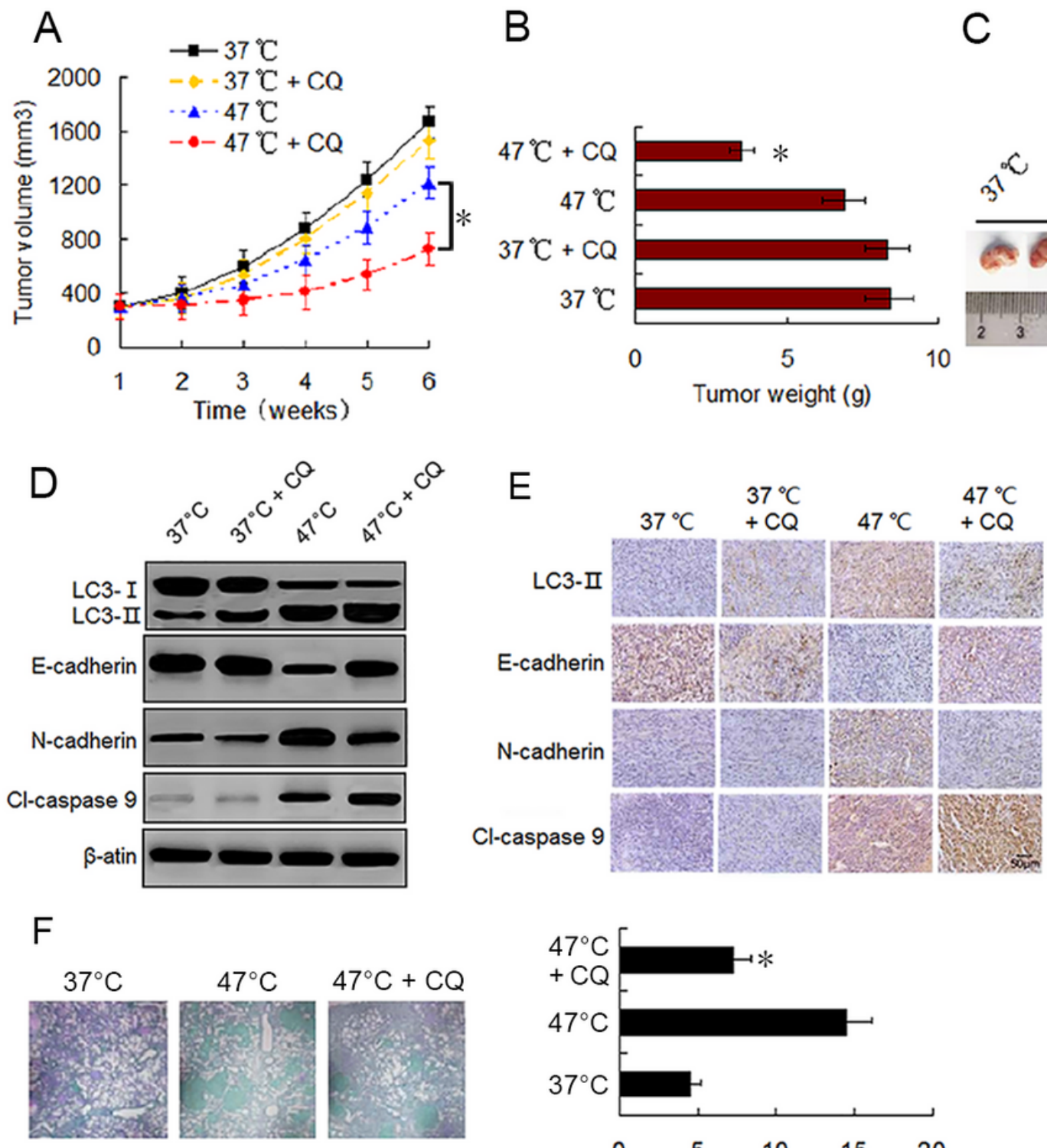

Fig. 7

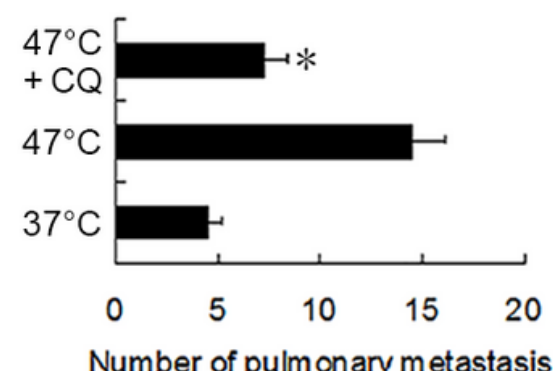

Number of pulmonary metastasis

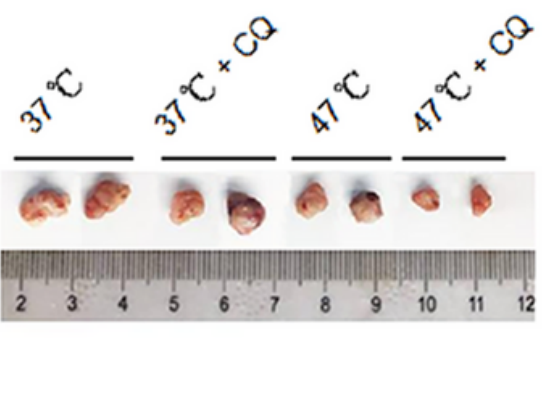




\section{Figure 7}

Autophagy inhibitor potentiates the antitumor effect of heat treatment and depresses heat treatmentinduced metastasis of $\mathrm{BC}$ cells in vivo. A, B MDA-231 cells pretreated with $47^{\circ} \mathrm{C}$ for 30 min or maintained at $37^{\circ} \mathrm{C}$ were subcutaneously injected into the mammary fat pad of female BALB/c nude mice. The mice receiving different pretreated cells were treated with or without $C Q$, respectively. Tumor volume was measured at the indicated time points after the onset of treatment $(A)\left({ }^{*}<<0.05\right)$. The tumor weight was measured at the end of the experiment (B) ( ${ }^{*} P<0.05$ vs $\left.47^{\circ} \mathrm{C}\right)$. C Representative picture of tumor samples from the mice receiving different treatment as indicated. $D$ The results of western blotting and $E$ immunohistochemistry analysis of the expressions of proteins as indicated in MDA-231 cell tumor samples from the mice receiving different treatment. F MDA-231 cells pretreated with $47^{\circ} \mathrm{C}$ for 30 min or maintained $37^{\circ} \mathrm{C}$ were injected through tail vein into female BALB/c nude mice. The mice were treated with or without CQ. After four weeks, the mice were sacrificed and the lung tissues were isolated. The lung tissues were sectioned serially and stained with HE. Representative images of HE staining of pulmonary metastatic foci (left). The number of metastatic foci were counted (right) $\left({ }^{\star} \mathrm{P}<0.05\right.$ vs $\left.47^{\circ} \mathrm{C}\right)$.

\section{Supplementary Files}

This is a list of supplementary files associated with this preprint. Click to download.

- AdditionalfilesFiguresS15.pdf 